\title{
Homeowners Association
}

National Cancer Institute

\section{Source}

National Cancer Institute. Homeowners Association. NCI Thesaurus. Code C54141.

An organization comprised of all owners of units in the development. 